\title{
How Have Climate Emergency Declarations Helped Local Government Action to Decarbonise?
}

\author{
James Dyson and Calum Harvey-Scholes
}

Highlights Commitments within local government CEDs chart a course for faster community-level decarbonisation with participatory democracy. To move forward faster, local approaches must be equitable, coordinated and sufficiently resourced and empowered.

Keywords Climate emergency declarations · Framing · Enabling environment · Engagement · Ambition · Local government

J. Dyson ( $\otimes)$

Grantham Research Institute, LSE, London, UK

Shoreham-By-Sea, Ricardo, UK

London School of Economics, London, UK

C. Harvey-Scholes

Energy Policy Group, University of Exeter, Penryn Campus, Penryn, UK

(C) The Author(s) 2022

C. Howarth et al. (eds.), Addressing the Climate Crisis, https://doi.org/10.1007/978-3-030-79739-3_5 


\section{INTRODUCTION}

The reduction of carbon emissions is urgently needed to avoid climate breakdown and local government has a critical role in delivering it (CCC, 2020a). Local governments can lead and coordinate climate action, establishing a local enabling environment for emissions reduction across the public and private sectors, and ensuring efforts are informed by meaningful engagement with people. This chapter presents analysis of the more than three hundred UK local governments who have now declared a 'climate emergency', drawing on interviews as well as the declaration texts themselves. This chapter discusses whether the emergency rhetoric and declarations have accelerated policy change, how they may affect the role of local government in decarbonisation, and what could help local governments reduce emissions faster.

\section{The Role of Local Climate Governance in the UK}

The importance of the role of local government in achieving the UK's goal of an ambitious $63 \%$ reduction in carbon emissions compared to 2019 levels by 2035 is increasingly recognised (Amundsen et al., 2018; BEIS, 2020; CCC, 2020b). However, the past decade of austerity has seen central government funding for local government halve, meaning a $27 \%$ real terms reduction in spending power (National Audit Office, April 2019). In addition, the withdrawal of the National Reporting Framework for local government in 2011, which included environmental metrics, has weakened local government's ability to address the low carbon agenda (Dixon \& Wilson, 2013). Consequent reductions in environmental policy capacity in UK local governments (Eckersley \& Tobin, 2019) have resulted in considerable variation in activity to implement sustainable energy systems across the country (Britton, 2018; Tingey \& Webb, 2020). Finances and limitations to political authority both constrain local governments' capacity for action, and overcoming current circumstances has required innovation from local governments (Kuzemko \& Britton, 2020).

\section{The Growth of Local Climate Action}

Despite these challenges, the past two years have seen a groundswell in local climate action around the UK and many local governments have 
shown real ambition to accelerate the UK's journey to net-zero. 2019 saw interest in and concern for climate change among the UK public reach their highest in decades (Skinner, 2019; UNDP and University of Oxford, 2021). Climate Emergency Declarations (CEDs) have now been passed by the majority of UK Tier 1 and 2 local governments (such as borough or county councils, unitary authorities and district councils), in many cases influenced by supportive civil society and resident groups. These can be used as an indicator to map the short-term local government policy response to this grassroots movement for climate action, as shown in Fig. 5.1.

Local government CEDs have contributed to normalising a new, more urgent 'frame' for climate change. The declarations redefine climate change from a technical challenge to a narrative which leverages the most recent climate science to emphasise an urgent 'climate emergency' in need of rapid redress. CEDs also emphasise the human consequences of failing to address climate change, stressing the moral responsibility of local government to act. The changing climate is already making life more challenging for people living in vulnerable regions, including small holder farmers (Harvey et al., 2018) and small island states (Monioudi et al., 2018), whilst the threat of runaway climate change is causing an intensifying cognitive burden for younger generations (Clayton, 2020). These ideas are visible in the CED texts. In making these declarations, local

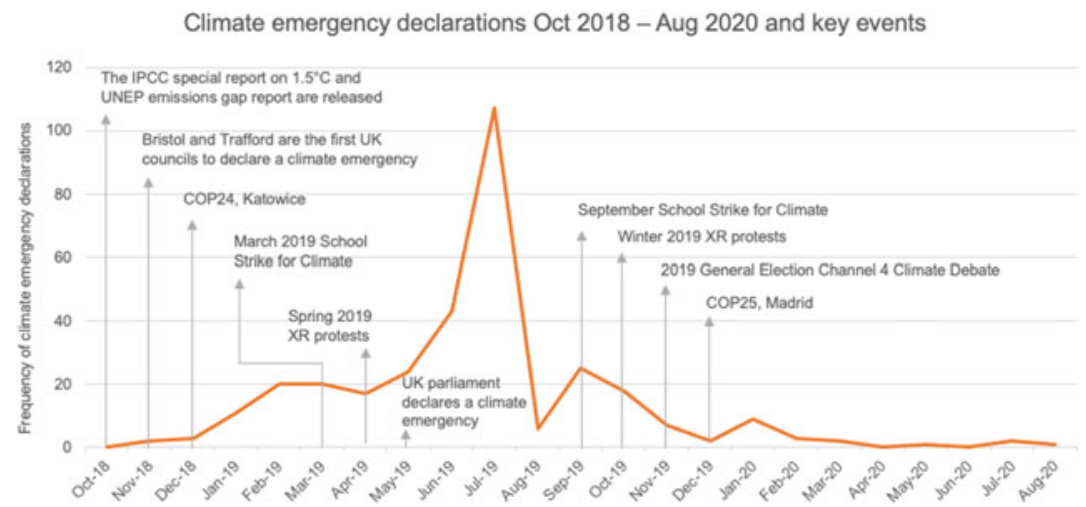

Fig. 5.1 CEDs by month, October 2018 to August 2020 with key events 
governments have helped to normalise the urgency of the problem and (re)positioned themselves as centrally engaged in tackling it.

The majority of UK local government CEDs had a focus on climate mitigation and were substantiated with ambitious net-zero targets and commitments to take the steps needed to reach those targets. Furthermore, most declarations and plans made public participation, often involving young people, a core aspect of devising their routes to net zero (Grantham Institute, 2021). In the year or so that has followed the CEDs, progress on the commitments includes (as of January 2021) 225 of 404 UK local governments having produced new climate action plans to reach net-zero targets. Two-thirds of these aim for a net-zero target ahead of the government's 2050 target (a large number of these aim for 2030).

The arguments presented in the rest of this short chapter are based on the outcomes of the authors' research projects ${ }^{1}$ which analysed the content of over 300 UK CED texts and supplemented this with a macroanalysis of every local government's climate ambitions as of 2020. In addition, 48 councillors, council officers and local residents from 26 UK local authorities across England and Scotland were interviewed between July 2019 and July 2020 on how they viewed the role to be played by these declarations. Analysis of this broad set of data provides insights into the nature of the CEDs as well as the social and policy environment in which they emerged.

\section{An 'Enabling EnVironment' FOR LOCAL EMISSIONS REDUCTION}

\section{Charting a Course: Motivation, Direction-Setting, and Targets}

We argue that the CEDs have prompted local government, to varying degrees, to establish conditions which encourage and enable local carbon emissions reductions. As one council employee observed, 'It's definitely stepped everything up .... And we needed it really [...] because it would have been business as usual'. Through gearing internal processes to deliver plans and achieve ambitious targets, utilising governmental policy and authority and facilitating public engagement and participation, whilst not

${ }^{1}$ Research was part of an MSc thesis, ESRC-funded PCAN work and the EPSRCfunded IGov project. 
comprehensive, local authorities can be seen to be creating an 'enabling environment' (Bulkeley \& Kern, 2006).

Elected officials and officers in local government expressed the feeling that the declarations empowered the councils to take action-showing people within councils that they could control their own futures and decisions on this issue. Councillors, local government officers and civil society members spoken to, believe the declarations have been effective tools to add formality and legitimacy to the need and mandate for faster action, making climate 'more of a mainstream issue that everyone has to think about'. The declarations disrupted the social fabric of local governments, raising the profile of the issue and empowering officials to act. This empowerment has enabled newly ambitious climate strategies, such as creating an action plan, ensuring appropriate and effective governance, and monitoring progress. Of course, whilst these foundational steps represent an advance on the status quo, their translation into practice and the acceleration of decarbonisation will ultimately determine success.

In addition, many CEDs directly committed local governments to institutional reforms: such as, establishing climate responsibilities in Cabinet and other committees, adding a climate impact assessment to their decision-making processes, ensuring strategic policy alignment with zero carbon and running local engagement forums. For example, Manchester City Council have introduced a $10 \%$ weight for climate change in their decision-making framework (CCC, 2020a). Looking to influence building development in the wider area, others have begun a review of their Local Plan in order to align it with their CED (e.g. Basingstoke \& Deane Borough Council, Cotswolds District Council, and Stafford Borough Council). Overall, normalising and formalising the climate emergency within local government processes and activity, as well as regulating and steering others, provides a clarity of purpose and a shared trajectory for emissions reduction.

\section{Public Engagement: Consent and Accountability}

Civil society has played a role in elevating climate on the policy agenda and promoting the climate emergency frame-consider the widelypublicised Extinction Rebellion occupations, the Fridays for Future school strikes and Greta Thunberg's blunt candour in addressing those in authority. More directly, we have observed residents' groups initiating 
the CED process and frequently collaborating with elected officials, encouraging them to raise motions and demonstrating public support.

The CEDs commit to engage with the community, often with young people specifically; some invoke youth parliaments and at least 18 have already carried out citizens' assemblies. Deliberative engagement exercises such as citizens' assemblies and juries have emerged as a newly prominent feature in policy development-examples include Camden Borough Council, Kendal Town Council and Oxford City Council. Increasing deliberative exchange between civil society and policymakers has the potential to establish a social mandate for action and engage new social groups in local climate action (Howarth et al., 2020). The way the council reached out to citizens ahead of declaring a climate emergency suggests how CEDs involved new people and politicians in local climate action. As described by one resident:

Jane's name was pulled out. She wasn't initially a climate activist and was more kind of from a strong trade union background. She spoke to a lot of people in her ward that had started to do work on the climate crisis.

Effective publicity of these (arcane and novel) processes is important for public buy-in as well as an opportunity for raising awareness of the climate issue more widely.

There are early, promising signs that the increased engagement between civil society and policymakers can continue, with citizens monitoring policy progress and expressing their (dis)approval. In an early example of ongoing engagement, Bury Council received sharp criticism in early 2020 for not making good on the promises made in their CED, leading the council to revise their budget. Ongoing accountability will partly depend on the extent to which local civil society organisations hold their elected officials to account.

\section{MOVIng Forward FASTER}

Declaring a climate emergency signals a direction of travel and, in many cases, indicates the required speed. Progress requires practical policy to drive carbon emissions reduction. Pushing the metaphor a little further, in order to arrive in time, action must accelerate-the current cruise control simply will not get us to the destination in time to avoid catastrophic heating (UNEP, 2020). As we have seen, preliminary activity has 
prepared an environment for action within institutions and, importantly, begun engagement with businesses and residents to co-create solutions and aspirations. In order to deliver faster progress, local governments may explore a more active role in certain areas (Britton, 2018). For example, local governments have led the development of district heat networks for decades in the UK (e.g. Sheffield City Council, Islington Borough, Gateshead Council) and successful municipal local transport provision persists (e.g. Lothian Buses, Reading Buses), with the idea being considered elsewhere (e.g. Cornwall). Bristol City Council's Bristol City Leap project aims to leverage private sector investment to deliver a city-scale low-carbon energy transformation programme. Given that many of the technological solutions are already at commercial scale, if the CEDs are interpreted as a genuine ambition to enact transformative policy, then the challenges local government faces in achieving the demanding rate of emissions reduction required by the science are primarily social, practical and political. More specifically, on the basis of our research, we identify three requirements for accelerating emissions reduction: public buy-in to policy and the wider agenda, coordination between and across scales to deliver on commitments, and the power and investment to act. We now briefly consider each of these in turn.

\section{The Limits to the Emergency Frame}

In order to include all groups in climate discussion and decision-making, public engagement communications must be tailored and often expressly related to diverse social, financial, and other local circumstances, as well as environmental benefits.

Our research identified a concern that 'climate emergency' may not be an engaging frame for people who are from socially and economically marginalised groups. For some people, declaring an emergency for climate change seems irrelevant or even marginalises the everyday emergencies that they experience. For those experiencing daily hardship such as precarious income, chronic illness or unstable housing, being able to treat climate change as an emergency may be inconceivable. Reducing inequality and poverty must be a core ambition within climate action strategies. The challenge of decarbonisation presents many opportunities to tackle both issues, simultaneously reducing hardship and carbon emissions, including retrofitting homes and reducing car traffic (MacNaughton et al., 2018; Sharifi, 2021). 


\section{Coordinating Action}

A combination of central coordination and local collaboration will be essential to meeting ambitious emissions reductions targets. Coordination across local governments is both challenging (Clar, 2019) and vital to achieving the goals set out in the CEDs (Bulkeley \& Kern, 2006; CCC, 2020a). Between local governments, devolved regions and the national governments, net-zero targets vary significantly; these varying aspirations are likely to cause challenges for coordinating action between local governments as well as with national government. A balance between local autonomy and central governance will help in areas such as energy system transformation (Willis et al., 2019). Evidence of innovative solutions is emerging; for instance, the Devon Climate Response Group aims to bring actors across the county together under a common net-zero vision and coordinated action plan. Local partnerships are forming, with the aim to coordinate climate action among businesses and communities, such as the Place-Based Climate Action Network (PCAN) commissions. Research and demonstrations to enhance our understanding of effective coordination across governmental scales, energy vectors and sectors are needed.

\section{The Available Power and Resource for Local Government}

Some local governments may partly overcome resource constraints, but fulfilment of ambitious CED commitments across the board will be expedited by financial support and devolution of powers from central government. An appeal to central government to provide the power and resource required to deliver on commitments is a common feature among the CEDs. Though policy to enable local action has been promised by the government (Hansard, 2019), delivering this will require both clear strategic direction-setting from Whitehall at the same time as providing autonomy to implement appropriate local solutions through powers and finance. Nonetheless, innovative local governments are finding ways to finance action in the absence of directly supportive central government policy: for example, Warrington and West Berkshire councils became the first councils to successfully lever low-cost private finance for renewable generation projects using 'green bonds' (WBC, 2021). Warwick Council, meanwhile, has announced a referendum asking residents whether they would accept increased council tax to fund climate action. 


\section{REFERENCES}

Amundsen, H., et al. (2018). Local governments as drivers for societal transformation: Towards the $1.5^{\circ} \mathrm{C}$ ambition. Current Opinion in Environmental Sustainability, 31, 23-29. https://doi.org/10.1016/j.cosust.2017.12.004

BEIS. (2020). Energy white paper: Powering our net zero future.

Britton, J. (2018). Localising energy: Heat networks and municipal governance. In Handbook of international political economy of energy and natural resources. Edward Elgar Publishing.

Bulkeley, H., \& Kern, K. (2006). Local government and the governing of climate change in Germany and the UK. Urban Studies, 43(12), 2237-2259.

CCC. (2020a). Local authorities and the Sixth Carbon Budget. https://doi.org/ $10.1016 / \mathrm{s} 0033-3506(44) 80323-7$

CCC. (2020b). The Sixth Carbon Budget-The UK's path to net zero. Available at: https://www.theccc.org.uk/publication/sixth-carbon-budget/

Clar, C. (2019). Coordinating climate change adaptation across levels of government: The gap between theory and practice of integrated adaptation strategy processes. Journal of Environmental Planning and Management, 62(12), 2166-2185.

Clayton, S. (2020). Climate anxiety: Psychological responses to climate change. Journal of Anxiety Disorders, 74, 102263.

Dixon, T., \& Wilson, E. (2013). Cities' low-carbon plans in an "age of austerity": An analysis of UK local authority actions, attitudes and responses. Carbon Management, 4(6), 663-680. https://doi.org/10.4155/cmt.13.58

Eckersley, P., \& Tobin, P. (2019). The impact of austerity on policy capacity in local government. Policy o Politics, 47(3), 455-472.

Hansard. (2019). Oral answers to questions 20th March, Hansard, volume 656. Available at: https://hansard.parliament.uk/Commons/2019-03-20/deb ates/9966CB46-DA75-40C2-BB07-8294CE9F4348/OralAnswersToQuest ions\#contribution-84F3A0B0-3106-4DE7-9473-F87BDB8B2E91. Accessed 8 January 2021.

Harvey, C. A., et al. (2018). Climate change impacts and adaptation among smallholder farmers in Central America. Agriculture \& Food Security, 7(1), 57. https://doi.org/10.1186/s40066-018-0209-x

Howarth, C., et al. (2020). Building a social mandate for climate action: Lessons from COVID-19. Environmental and Resource Economics, 76(4), 1107-1115. https://doi.org/10.1007/s10640-020-00446-9

Kuzemko, C., \& Britton, J. (2020, November 2019). Policy, politics and materiality across scales: A framework for understanding local government sustainable energy capacity applied in England. Energy Research and Social Science, 62, 101367. https://doi.org/10.1016/j.erss.2019.101367

MacNaughton, P., et al. (2018). Energy savings, emission reductions, and health co-benefits of the green building movement. Journal of Exposure Science of 
Environmental Epidemiology, 28(4), 307-318. https://doi.org/10.1038/s41 370-017-0014-9

Monioudi, I. N, et al. (2018). Climate change impacts on critical international transportation assets of Caribbean Small Island Developing States (SIDS): The case of Jamaica and Saint Lucia. Regional Environmental Change, 18(8), 2211-2225. https://doi.org/10.1007/s10113-018-1360-4

Sharifi, A. (2021). Co-benefits and synergies between urban climate change mitigation and adaptation measures: A literature review. Science of The Total Environment, 750, 141642. https://doi.org/10.1016/j.scitotenv.2020. 141642

Skinner, G. (2019). Concern about climate change reaches record levels with half now 'very concerned', Ipsos Mori. Available at: https://www.ipsos.com/ipsosmori/en-uk/concern-about-climate-change-reaches-record-levels-half-nowvery-concerned. Accessed: 11 January 2021.

Tingey, M., \& Webb, J. (2020). Governance institutions and prospects for local energy innovation: Laggards and leaders among UK local authorities. Energy Policy, 138, 111211. https://doi.org/10.1016/j.enpol.2019.111211

UNDP and University of Oxford. (2021). Peoples' Climate Vote. Available at: https://www.undp.org/content/undp/en/home/librarypage/climate-anddisaster-resilience-/The-Peoples-Climate-Vote-Results.html

UNEP. (2020). Emissions Gap Report 2020. Nairobi.

WBC. (2021). West Berkshire Community Municipal Investment (CMI). West Berkshire Council. Retreived from: https://info.westberks.gov.uk/wbcmi.

Willis, R., et al. (2019). Enabling the transformation of the energy system, IGov Project. Available at: http://projects.exeter.ac.uk/igov/wp-content/upl oads /2019/04/Enabling-the-transformation-of-the-energy-system-DRAFTFOR-COMMENTS.pdf 
Open Access This chapter is licensed under the terms of the Creative Commons Attribution 4.0 International License (http://creativecommons.org/licenses/ by $/ 4.0 /$ ), which permits use, sharing, adaptation, distribution and reproduction in any medium or format, as long as you give appropriate credit to the original author(s) and the source, provide a link to the Creative Commons license and indicate if changes were made.

The images or other third party material in this chapter are included in the chapter's Creative Commons license, unless indicated otherwise in a credit line to the material. If material is not included in the chapter's Creative Commons license and your intended use is not permitted by statutory regulation or exceeds the permitted use, you will need to obtain permission directly from the copyright holder.

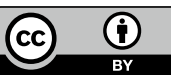

